\title{
E. M. Forster in margine ruského románu a několik dalších souvislostí
}

\author{
Lenka Paučová (Brno)
}

\begin{abstract}
Abstrakt
Předkládaná studie se zabývá literárněkritickou prací anglického spisovatele a teoretika Edwarda Morgana Forstera (1879-1970) Aspects of the Novel (Aspekty románu, 1927). Nejde pritom o první teoretickou práci o románu. Forsterova práce se váže $\mathrm{k}$ počátku 20. století, vzniká v čase, když už bylo několik teoretických prací o románu známých; na druhou stranu zejména počátek 20. století byl obdobím přehodnocování dosavadních poznatků v literární vědě i v samotné teorii románu. Autorka se ve Forsterově práci zaměřuje především na souvislosti s ruskou literaturou, konkrétně s romány L. N. Tolstého (Vojna a mír) a F. M. Dostojevského (Bratři Karamazovovi); ale také na teoretické vymezení románu, postavy a na polemiku s literárními vědci.
\end{abstract}

\section{Klíčová slova}

E. M. Forster; román jako žánr; ruská literatura; L. N. Tolstoj; F. M. Dostojevskij

\section{Abstract}

\section{E. M. Forster in margine on Russian Novel and a few Other Facts}

The present paper deals with the theoretical work Aspects of the Novel (1927) written by English writer and literary critic E. M. Forster (1879-1970). It is not the first theoretical work about the genre of the novel. Forster's work was created at the beginning of the $20^{\text {th }}$ century when some theoretical works about the genre of the - novel were known, but, on the other hand, the beginning of the $20^{\text {th }}$ century was the time when it came to reassessment of former methods and attitudes to a literary work, and also to the theory of the novel. The author of the paper focuses on connections with Russian literature, concretely with novels by L. N. Tolstoy (War and Peace) and F. M. Dostoyevsky (Brothers Karamazov), but also on definition of the novel, characters and polemics with other critics.

\section{Key words}

E. M. Forster; novel as a genre; Russian literature; L. N. Tolstoy; F. M. Dostoyevsky 


\section{Úvodem}

Za první monografii o ruské literatuře na Západě se považuje monografie Le roman russe (Ruský román, 1886) francouzského kritika Melchiora de Voguë. K tomu, že se práce tohoto charakteru objevila ve francouzském a ne jiném prostředí, přispěl ve druhé polovině 19. století příznivý vztah Francie k ruské literatuře - několik let zde žil I. S. Turgeněv, s jehož jménem se spojuje šíření povědomí o ruské literatuře především v Pařízii; Francie se stala již v 19. století domovem ruské emigrace, připomeňme osobnosti A. I. Gercena a N. P. Ogariova, vznikaly překlady ruských děl do francouzského jazyka a také díla francouzských spisovatelů byla překládána do ruštiny. ${ }^{1}$

Postupně se objevovaly další a další práce teoretické či kritické, a to nejen ve francouzském, ale také v anglosaském a německém prostředí; tyto se celkově nebo zčásti věnovaly ruské literatuře. K druhým ze zmiňovaných prací náleží také práce, jejímž autorem je anglický spisovatel a kritik Edward Morgan Forster (1879-1970). Jeho spis Aspects of the Novel (Aspekty románu, 1927) se podobně jako monografie francouzského kritika z hlediska žánru soustředí na román, primárně však na román anglický. Na druhé straně nelze zkoumat román bez stěžejních děl ruské a francouzské literatury, což si autor dobře uvědomoval. Ve své práci se proto v souvislosti s ruskou literaturou zaměřil na dva spisovatele - L. N. Tolstého a F. M. Dostojevského, ${ }^{2}$ již jsou právem považováni za velikány ruské klasické literatury a jejich díla za to nejlepší, co se v ruské literatuře zrodilo.

\section{Spisovatel a kritik v jedné osobě}

Forster se nacházel v podobné pozici jako Dostojevskij, byl spisovatelem, který ovlivnil i literární vědu. Do literatury vstoupil jako autor románů Where Angels Fear to Tread (1905, čes. 1987), The Longest Journey (1907), A Room with a View (1908) a Howard's End (1910, čes. 1982), později vyšly ještě A Passage to India (1924, čes. 1926) a Maurice (1971, čes. 2005); následovaly jeho povídky, eseje, hry a další. Podle Forstera by měl být spisovatel zároveň částečně i kritikem a kritik by měl v sobě najít umělce. Obrazně poukazuje na to, že literární tvorba a její hodnocení představují jakoby bájné obludy Scyllu a Charybdu: ani jedné by neměl být věnován př́liš velký prostor, protože v konečném důsledku tím dílo může hodně ztratit. ${ }^{3}$ Samotné hodnocení nejen románu, ale jakéhokoliv díla je podle Forstera náročné, protože hodnotíme podle vkusu, román se nám zalíbí, nebo ne: „Konečným testom románu bude náš citový vzt’ah $k$ nemu $[\ldots] . .4$

1 Např́klad i sám Dostojevskij se zabýval překlady z francouzské literatury. Přeložil román $\mathrm{H}$. de Balzaca Evženie Grandetová, jenž se považuje za první publikovanou práci spisovatele.

2 Forster se vyjadřuje jen o L. N. Tolstém a F. M. Dostojevském, žádného jiného ruského spisovatele ani dílo $\mathrm{v}$ textu nezmiňuje.

3 Srov. FORSTER, Edward Morgan: The Creator as a Critic and Other Writings by E. M. Forster. Edited by Jeffrey M. Heath. Toronto: Dundurn Press, 2008, s. 65.

4 FORSTER, Edward Morgan: Aspekty románu. Bratislava: Tatran, 1971, s. 42. 
Jak jsme již uvedli, do literární vědy Forster zasáhl svým teoretickým spisem Aspects of the Novel, jenž napsal v roce $1927 .{ }^{5}$ Pro svou práci si Forster vybral název záměrně vágní; název, jenž pro něj znamená větší tvưrčí svobodu. ${ }^{6}$ Forster se ve své práci věnuje sedmi románovým aspektům - příběhu (story), lidem (people), zápletce (plot), fantazii (fantasy), věštbě (prophecy), osnově (pattern) a rytmu (rhythm). Souvislosti s ruským románem uvádí téměř ve všech částech, nejvíc souvislostí však přináší v části Věštba, v níž srovnává román George Eliotové Adam Bede s románem F. M. Dostojevského Bratři Karamazovovi.

Inspirujícím se pro nás stává i samotný žánr Forsterovy práce. Jde o přednášky psané esejistickou formou, jež se autor s odstupem času rozhodl publikovat. Charakter textu nám umožňuje sledovat, jak autor - spisovatel, literární kritik a teoretik v jedné osobě - na přednášce komunikuje se svými posluchači, jak se k nim obrací, pokládaje otázky. Střídají se pasáže, jež jsou teoreticky a terminologicky zatíženy s volnějšími pasážemi.

Často se stává, že se vědec rozhodne soubor svých přednášek publikovat. Pro nás jsou podnětnými např́klad přednášky o Dostojevském z pera francouzského spisovatele André Gida, ale také Přednášky o ruské literatuře Vladimira Nabokova.

\section{Co je román?}

Na tuto otázku, jednoduchou i složitou zároveň, se snažili najít odpověd' již badatelé dávno před Forsterem, připomeňme například teoretické práce Pierra-Daniela Hueta De l'origine des romans a Jeana-Louise Prascha Reflexions sur les romans z konce 17. století. Připomeňme, že anglický román prožíval svůj vrchol v 18. století, proto vznikaly práce, jež se jím teoreticky zabývaly. Jak jsme již uvedli, v př́ípadě E. M. Forstera a jeho literárněteoretické práce Aspects of the Novel nejde o první práci zabývající se románem, ale zejména tento anglický spisovatel a kritik prezentoval kvalitativní hledisko a vymezil tak tento žánr na základě konkrétního počtu stran. ${ }^{7}$ Podle Forstera dílo může být románem, když má rozsah minimálně 50000 slov. S vtipem a nadsázkou poznamenává, že „ak sa vám to vidi nefilozofické, vymyslite láskavo nejakú inú definiciu“8. Teoretické vymezení žánru jen na základě kvantity je samozřejmě obecné a nepřesné, protože k románu bychom tak na základě této definice mohli řadit například i delší pohádku, pověst, memoáry a další. I samotný deník může obsahovat 50 000, ale také více slov a řadit se k románu.

Román musí být definován na základě rozsahu, ale tato charakteristika nemůže zůstat jedinou. Rozsah by podle nás měl být dominantní charakteristikou tohoto žánru, ale

5 Tato Forsterova práce zatím do českého jazyka přeložena nebyla. V roce 1971 vyšel však její slovenský překlad Evy Šimečkové, která Forstera slovenské literární veřejnosti představila také v úvodní studii Pokus E. M. Forstera o teóriu románu. Viz FORSTER, Edward Morgan: Aspekty románu. Bratislava: Tatran, 1971. $140 \mathrm{~s}$.

6 Forster píše: „Vybral som si názov Aspekty, lebo je nevedecký a vágny, lebo nám ponecháva maximum slobody a umožňuje nám, aj samému autorovi všimat' si román z viacerých stránok. " Tamtéž, s. 42.

7 Nutno poznamenat, že Forster vychází z práce teoretika Abela Chevalleyho Le Roman anglais de notre temps (1921), v níž je román definován jako umělecká próza určitého rozsahu. Na Chevalleyho práci Forster v textu přímo odkazuje. Srov. tamtéž, s. 31.

8 Tamtéž. 
nutno k ní vymezit i charakteristiky variabilnị̂; tedy ty, které se od románu k románu mohou měnit. Kromě rozsahu Forster za základní charakteristiku románu považoval aspekt vyprávění příběhu. ${ }^{10} \mathrm{~V}$ žánrovém podloži (termín I. Pospíšila) románu se nachází mýtus, epos (samotný pojem již znamená vyprávění) a další prozaická vyprávění. ${ }^{11}$ Epos byl charakterizován epickou šíríí, tudíž ani román nemůže mít pět stránek.

Ve Forsterově pojetí se román spojuje s neurčitostí, vnímá ho doslova jako „močaristý terén “. ${ }^{12}$ Podle nás to souvisí s tím, že román se vyznačuje velkým polymorfním rozpětím (termín I. Pospíšila) ${ }^{13}$, umožňuje spisovateli do sebe integrovat další žánry. Co se týče vyvrcholení a rozuzlení, vyvrcholení př́iběhu svatbou Forster ostře odsoudil, považuje ho doslova za idiotské. ${ }^{14}$ Jeho slova nám nemohou nepřipomenout teoretické náhledy N. S. Leskova, jenž kritizoval řešení konfliktu rovněž svatbou nebo sebevraždou hlavního hrdiny. ${ }^{15}$ Forster doslova uvádí, že „keby nebolo smrti alebo sobáša, neviem, ako by priemerný románopisec zakončil svoj román." ${ }^{16}$ Většina románů se podle Forstera vyznačuje slabým závěrem; dílo ke konci začne jakoby ochabovat, postavy postupně umírají, takže na konci zůstává dojem smrti, mrtvosti. ${ }^{17}$

Podle Forstera je román žánrem o lidech, o lidském charakteru, o lidskosti. O antropologickém charakteru žánru se vyjadřuje následovně: „Mali by sme hlbšie skúmat’ l’udskú kvalitu románu; román je presiaknutý l'udskostou; citovému povzneseniu alebo prívalu citov nemožno uniknút’ a nemožno ich z kritiky vylúčit'. Môžeme l'udskost’odmietat', ale ak ju z románu odstránime alebo celkom vylúčime, román zvädne a ostane iba kôpka slov."18 Antropologický charakter románu akcentují zejména části Forsterovy práce o postavách (Lidé, Lidé pokračování), jimž je věnováno v práci nejvíce prostoru; ale také terminologie z oblasti antropologie, kterou autor v celé práci využívá.

9 O dominantních a variabilních složkách žánru psal M. M. Bachtin. Viz BACHTIN, M. M.: K metodologii literaturovedenija. In: Kontekst 1974. Literaturno-teoretičeskije issledovanija. Moskva: Nauka, 1975, s. $203-212$.

10 E. M. Forster uvádí, že „v románe sa rozpráva príbeh. To je základný aspekt, bez ktorého by román nemohol existovat'. To je najdôležitejši faktor spoločný všetkým románom. " FORSTER, Edward Morgan: Aspekty románu. Bratislava: Tatran, 1971, s. 43.

11 Srov. POSPÍŠIL, Ivo: Literární genologie. Brno: Masarykova univerzita, 2014, s. 28.

12 FORSTER, Edward Morgan: Aspekty románu. Bratislava: Tatran, 1971, s. 42.

13 Tento termín Pospíšil používá v souvislosti s dílem A. P. Čechova Ostrov Sachalin, jež se vyznačuje polymorfností, vícežánrovostí. Viz POSPÍŠIL, Ivo: Rozpětí žánru. Brno: SPRINT-PRINT, 1992, s. 70-78.

14 Srov. FORSTER, Edward Morgan: Aspekty románu. Bratislava: Tatran, 1971, s. 51.

15 N. S. Leskov tzv. dramatický román po vzoru I. S. Turgeněva nebyl schopen napsat. Ivo Pospísil uvádí tyto příčiny: těsnost románové struktury, její menší schopnost spojovat různorodý materiál a neschopnost autora uzavřít sdělení do přísné formy. Srov. POSPÍŠIL, Ivo: Proti proudu. Studie o N. S. Leskovovi. Brno: SPRINT-PRINT, 1992, s. 35.

16 FORSTER, Edward Morgan: Aspekty románu. Bratislava: Tatran, 1971, s. 88.

17 Tamtéž, s. 87.

18 Tamtéž, s. 42. 


\section{Ruská literatura a ruský román}

Obdiv k ruské literatuře vyjadřuje Forster již na začátku publikace, vidíme tedy, jak se západní literatura a literární věda před ruskou literaturou sklání a nachází v ní inspiraci. ${ }^{19} \mathrm{~V}$ době vzniku Forsterovy práce o románu se však povědomí o ruské literatuře na Západě omezovalo zejména na velikány. Jména jako L. N. Tolstoj a F. M. Dostojevskij znal téměř každý. Proč se na Západě setkáváme se zájmem o tvorbu ruských spisovatelů? Jde především o psychologický román, jehož tradice se zejména po vzoru Dostojevského rozvíjela dále v tvorbě francouzských a britských spisovatelů. Faktem však zůstává, že na Západě získávala čtenářská veřejnost o ruské literatuře zkreslený pohled, což si uvědomoval i samotný Forster. Ve svých esejích uvádí, jak četl teoretickou práci o ruské literatuře z pera Maurice Baringa, která opomíjí tvorbu Maxima Gorkého nebo další osudy ruské literatury v časech Sovětského svazu. ${ }^{20}$

Již v Úvodu ke své publikaci, v němž Forster srovnává anglickou a ruskou literaturu, vyzdvihuje velikost L. N. Tolstého a F. M. Dostojevského slovy: „Nijaký anglický románopisec nedosahuje vel'kost' Tolstého [...] nikto nepodal taký úplný obraz l’udského života, jeho všednej, ale aj hrdinskej podoby. [...] Nijaký anglický románopisec neprebádal l’udskú dušu do takej hĺbky ako Dostojevskij. "21 Nesmírný př́nos zmiňovaných ruských spisovatelů v textu dále akcentuje, když poukazuje na čtyři romány Cranford, Jane Eyre, Richard Ferevel a The Heart of Mildlothian: „Ale všstky štyri romány sú iba skromnými stavbami a nie mohutnými palácmi, a my by sme ich mali vnimat’ a vážit’ si ich pre to, čím sú, ak ich na okamih postavime do stíporadia Vojny a mieru alebo pod klenbu Bratov Karamazovovcov."22

Proč zejména Tolstého a Dostojevského? A ne například Puškina a Lermontova, Lermontova a Gercena atd.? Dlužno ještě zmínit, že spisovatelé a literární vědci na Západě znali tvorbu ruských spisovatelů hlavně z překladů, překládány byly v první řadě nejslavnější romány Tolstého a Dostojevského. Forster však zmiňuje jen Vojnu a mír a Bratry Karamazovovi. To samé platí i o esejích ${ }^{23}$, v nichž Forster uvádí souvislosti jen s uvedenými romány, jiná díla, ani v té době již dobře známé romány jako Tolstého Anna Kareninová nebo Dostojevského Zločin a trest, nepřipomíná. Tolstého a Dostojevského vidí jen jako romanopisce, autory jednoho románu.

19 V eseji uvádí „one curious fact will strike you - how modern is Russian literature. It scarcely exists before 1800. Although it is so national, it did not develop through the centuries like the literatures of France or England. [...] It is like the child, full of energy and hope. And it has a child's knack of going straight to the heart of things. "FORSTER, Edward Morgan: Some Books: The Brothers Karamazov and Bhakti. In: The Creator as a Critic and Other Writings by E. M. Forster. Edited by Jeffrey M. Heath. Toronto: Dundurn Press, 2008, s. 256.

20 Jde konkrétně o teoretickou práci Russian Literature, slovy E. M. Forstera: „There is scarcely anything about Gorki in it, and nothing about the development of literature under the Soviet." Tamtéž, s. 256.

21 FORSTER, Edward Morgan: Aspekty románu. Bratislava: Tatran, 1971, s. 32.

22 Tamtéž.

23 Viz The Creator as a Critic and Other Writings by E. M. Forster. Edited by Jeffrey M. Heath. Toronto: Dundurn Press, 2008. 


\section{Román L. N. Tolstého Vojna a mír}

Román L. N. Tolstého Forster srovnává s románem A. Bennetta The Old Wives’ Tale, přičemž poukazuje na to, že román ruského spisovatele nevyznívá tak pošmourně nebo doslova depresivně jako román Bennettův. V Tolstého románu akcentuje kategorii prostoru více než kategorii času: „Vel'a románopiscov má zmysel pre miesto [...]. Ale iba máloktorí majú zmysel pre priestor, u Tolstého je tento zmysel najuyššou súčastou jeho umeleckého posvätenia. Vo Vojne a mieri dominuje Priestor, a nie Čas. "24

K románu Vojna a mír se Forster ještě vrací v části Osnova a rytmus, v níž rytmus definoval jako opakování neboli variaci, v této souvislosti ho spojuje s motivy, které se v díle opakují. Vojna a mír má rytmus, i když je to podle Forstera neorganizovaná kniha. ${ }^{25}$ Zajímavostí je, že tuto „neorganizovanou knihu“ Forster klade na první místo, za ní, na druhém místě, se nachází Bratři Karamazovovi.$^{26}$ Své stanovisko dále nezdůvodňuje.

\section{F. M. Dostojevskij}

O F. M. Dostojevském se Forster vyjadřuje mnohem explicitněji v části s názvem Věštba. Ruský spisovatel je očima Angličana samozřejmě významným, velkým spisovatelem. Aspekt věštby jako jeden $\mathrm{z}$ aspektů románu představuje průnik do spisovatelovy dikce ${ }^{27}$, zahrnuje v sobě víru nebo zintenzívnění některého z lidských citů. V dané souvislosti Forster vymezuje tzv. věštecký román neboli román věštby ${ }^{28}$, $\mathrm{k}$ jehož stěžejným rysům řadí pokoru, nedostatek smyslu pro humor, návrat k soucitu a lásce. Dostojevského zároveň označuje za jednoho ze čtyř spisovatelů${ }^{29}$, jež napsali román vyznačující se uvedenými rysy.

Dostojevského postavy jsou podle Forstera plastické, v souvislosti s postavou Dmitrije Karamazova uvádí, že s těmito postavami prožíváme nejen jejich osud, ale i něco víc, něco hlubšího než jen zážitky. ${ }^{30} \mathrm{~S}$ Dostojevského postavami prožíváme jejich sny, jimiž jsou propojeny s nekonečnem, což můžeme vidět v následující citaci: „U Dostojevského je vždy niečo za postavami a za situáciou; sú prestúpené nekonečnom, a hoci ostávajú individuálne, objimajú nekonečno a vyzývajú ho, aby ich objalo [...].“31

24 FORSTER, Edward Morgan: Aspekty románu. Bratislava: Tatran, 1971, s. 52.

25 Srov. tamtéž, s. 129.

26 „It is The Brothers Karamazov, and it is the second greatest novel, I think; the greatest of all being is Tolstoy 's War and Peace." FORSTER, Edward Morgan: Some Books: The Brothers Karamazov and Bhakti. In: The Creator as a Critic and Other Writings by E. M. Forster. Edited by Jeffrey M. Heath. Toronto: Dundurn Press, 2008, s. 256 .

27 Forster doslova píše: „Veštba - v našom význame - je tón hlasu. “FORSTER, Edward Morgan: Aspekty románu. Bratislava: Tatran, 1971, s. 103.

28 V anglickém originálu Forster použíá termín prophetic fiction, proto podle nás mohla překladatelka raději zvolit ekvivalent věštecká próza a ne věštecký román, jak se uvádí ve slovenském překladu; i když se autor zabývá zejména románem.

29 Kromě F. M. Dostojevského Forster uvádí ještě H. Mellvilla, D. H. Lawrence a E. Brontëovou.

30 FORSTER, Edward Morgan: Aspekty románu. Bratislava: Tatran, 1971, s. 108.

31 Tamtéž, s. 107. 
O románu F. M. Dostojevského Bratři Karamazovovi se Forster mnohem explicitněji vyjadřuje ve svých esejích ${ }^{32}$. Kromě kriminální zápletky vidí i hlubší souvislosti, a to Dostojevského naději a víru v dobro, kterou cítíme v celém románu, především však na jeho konci: „The Brothers Karamazov is indeed a marvellous book, and I have still to mention its greatest marvel. For it has something in it which doesn't exist elsewhere in literature. It's more than a murder story. It's more than a revelation of evil. It's an embodiment of good. "33 Proč? Forster se na román dívá očima spisovatele, proto vidí i tyto souvislosti, nejen zvláštnosti na úrovni kompozice, narace nebo syžetu.

\section{„Zalidnění“ románu}

Nejdřív bychom chtěli zdůraznit, jak se pojetí literární postavy mění, a to v první řadě v závislosti na zvoleném literárněvědném přístupu, ale také na literárním období a žánru. Na postavu bylo nahlíženo z různých perspektiv: jako součást tématu představovala kategorii tematickou (Hrabák), čímž byla naznačována také její propojenost s motivy (Tomaševskij), nebo byla vnímána jako součást příběhu a tím považována za kategorii naratologickou (poststrukturalisté); někdy byl zdůrazňován psychologismus, propojení postavy s autorem (Potebňa), nebo naopak propojení se sociálním prostředím; někdy byla role postavy zveličována (realistická charakterologie a charakterologie obecně, typická zejména pro ruské prostředí), jindy byla vnímána jako součást postupu vzniku díla nebo možnosti, jak literární dílo ozvláštnit (formalisté). Ivo Pospíšil v této souvislosti kategorii postavy nazývá lakmusovým papírkem metodologií a přístupů, protože způsob, jakým literární vědec na postavy nahlíží, odhalí i jeho orientaci. ${ }^{34}$

Jak jsme již uvedli, Forsterův přístup k literárnímu dílu lze podle nás označit za antropologický, zejména postavám věnoval ve své práci největší prostor, nazývaje je herce př́běhu (actors). Poukazuje však i na to, že v románech se kromě postav lidí objevila také zvířata, ale bez většího úspěchu, což je důsledkem neznalosti jejich psychologie: „V románoch sme mali už aj živočichy, ale bez vä̌čsieho úspechu, lebo zatial' ich poznáme velmi málo po psychologickej stránke. "35

32 Viz FORSTER, Edward Morgan: Some Books: The Brothers Karamazov and Bhakti. In: The Creator as a Critic and Other Writings by E. M. Forster. Edited by Jeffrey M. Heath. Toronto: Dundurn Press, 2008, s. 255-258.

33 Tamtéž, s. 257.

34 Srov. POSPÍŠIL, Ivo: Literárni postava jako „zašité nůžky “ literárni vědy. In: Sborník prací Filozofické fakulty Brněnské univerzity, X 4, 2001, s. 51.

35 FORSTER, Edward Morgan: Aspekty románu. Bratislava: Tatran, 1971, s. 54. Jako nositelé lidských vlastností se zviŕrecí hrdinové tradičně objevovali v bajkách a pohádkách, v ruské literatuře se zejména koncem 19. století pod vlivem moderny objevují postavy zviřat i rostlin v povídkách, na jejichž základě ruští formalisté definovali postup tzv. ozuláštnění (rus. ostraněnije). Viktor Šklovskij se ve své stěžejní práci Teorie prózy bliže věnuje Tolstého novele Cholstomer, jež je ozvláštněna opisováním událostí z perspektivy animálního vypravěče - koně. Poukazuje na to že Tolstoj využil ozvláštnění i v dílech z pozdějšího období, v nichž se zabýval dogmaty a obřady, a to když náboženskou terminologii nahrazoval slovy v jejich původním významu, což bylo následně chápáno jako rouhání. Srov. ŠKLOVSKIJ, Viktor: Teória prózy. Bratislava: Tatran, 1971, s. 17-21. 
Postavu bychom ve Forsterově pojetí mohli považovat za antropologickou dominantu, centrum nebo centrální aspekt románu, který je propojen s ostatními aspekty. Autor rozlišuje dva typy postav - ploché (flat) a plastické (round); později v textu, jako by si autor uvědomil nebezpečí typologie založené na dualitě, naznačuje ještě třetí typ - postavy se sklonem neboli tendenci $k$ plastičnosti (capable of rotundity; beginning of the curve towards the round). Dickensovy postavy jsou podle Forstera skoro všechny ploché, postavy v ruských románech jsou většinou plastické. Tendenci k plastičnosti pozoruje např́klad v postavách Jane Austenové.

Dále se Forster dotýká postav F. M. Dostojevského. Uvádí, že všechny jeho postavy jsou plastické. ${ }^{36} \mathrm{~S}$ tímto tvrzením bychom souhlasit určitě nemohli, protože Dostojevskij nebyl jen autorem románů, ale také střední a tzv. drobné epiky ${ }^{37}$. V jeho ranní a pozdní tvorbě najdeme různé typy povídek (například sváteční, humorná, satirická, fantastická), jejichž hrdinové podle nás k plastickým postavám určitě nepatří. Když se podíváme na satiru, tyto postavy se nevyvíjejí, jsou přemrštěné, charakterizovány na základě kritizované vlastnosti. Dodejme, že některé ze svých povídek z pozdějšího období Dostojevskij vložil do Deniku spisovatele. ${ }^{38}$

Forster vyjmenoval pět hlavních faktů v životě člověka, a to narození, jídlo, spánek, lásku a smrt. Každý spisovatel je zpracovává jinak, věnuje jim různý prostor. V souvislosti se spánkem nás zaujalo, že se Forster vyjadřuje o snech, které autoři využívají jako prostředek charakteristiky hrdiny. ${ }^{39}$ I když ve dvacátých letech 20. století byl v Británii vlivnou filozofií vitalismus H. Bergsona, u Forstera cítíme spíše vliv M. Heideggera, a to $\mathrm{v}$ důsledku jeho interpretace lidského života jako pohybu k smrti. ${ }^{40}$

Forster poukazuje na případ, když je román zaměřen na postavu: „Všetko sa krúti iba okolo hlavnej hrdinky. " ${ }^{11}$ Za takový typ románu Forster považuje román D. Defoea Moll Flandersová. ${ }^{42}$ Bohumil Fořt se Forsterově typologii věnuje ve své práci Literárni postava (2008). Kategorii postavy vnímá v souvislosti s dějem jako komplementární kategorie. ${ }^{43}$

36 „Pokial' ide o plastické postavy ako také, samy sa definujú už obsahom tohto slova a viac netreba dodávat'. [...] Sú to všetko hlavné postavy vo Vojne a mieri, všetky postavy Dostojevského a niektoré Proustove [...]." FORSTER, Edward Morgan: Aspekty románu. Bratislava: Tatran, 1971, s. 76.

37 Termín, jenž využívá ve své Poetice (1. vydání v roce 1973) Josef Hrabák (1912-1987). K drobné epice řadí např́iklad anekdotu, bajku, parabolu, pohádku, pověst a další; povídku, novelu a romaneto k střední epice. Viz HRABÁK, Josef: Poetika. Praha: Československý spisovatel, s. 253-258.

38 Připomeňme povídku Bobek, která je součástí Deniku spisovatele za rok 1873; do listopadového čísla z roku 1876 Dostojevskij zařadil kratší novelu Krotká, další novelu Sen směšného člověka najdeme v Deníku spisovatele za duben 1877.

39 „Sny uvádza autor do románu s určitým zameraním, nie aby nimi osvetlil celý život postavy, ale iba tú čast', ktorú prežíva v bdelom stave." FORSTER, Edward Morgan: Aspekty románu. Bratislava: Tatran, 1971, s. 61.

40 Pro zajímavost uvádíme, že Heideggerův filosofický spis Bytí a čas (něm. Sein und Zeit, 1927), v němž je lidský život definován jako pohyb ke smrti, vychází ve stejném roce jako Forsterova práce Aspekty románu.

41 FORSTER, Edward Morgan: Aspekty románu. Bratislava: Tatran, 1971, s. 66.

42 Na tomto místě bychom chtěli poukázat na to, že v ruské literatuře se můžeme setkat s podobným románem. Jde o román M. J. Lermontova Hrdina naši doby (1840), v němž jsou kompozice a příběh podřízeny hlavní postavě, kterou je důstojník Grigorij Alexandrovič Pečorin.

43 B. Fořt uvádí: „Přestože oba pokusy o uchopeni kategorie literárni od sebe děli dva tisíce let, nemůžeme turdit, že se z pojeti Aristotelova kontinuálně vyvinulo Forsterovo, že jedno vývojově prekonává druhé. Aristotelés a Forster však 
Konstatuje: „Nezdá se bohužel, že tyto dvě kategorie mohou být př́nosné pro možnou typologii narativnich postav $v$ závislosti na jejich atributech a zpiosobu charakterizace - předevšim vzhledem k subjektivni povaze aktu čteni a čtenářského hodnoceni. “44 Fořt poukazuje na dynamické hledisko, ve Forsterově pojetí se ploché postavy nevyvíjejí, můžeme předpokládat jejich konání. Na druhou stranu, plastické postavy se vyvíjejí, mohou nás svým konáním překvapit.

$\mathrm{V}$ případě F. M. Dostojevského se postavy vyvíjejí ve vztahu ke své koncepci. ${ }^{45}$ Dostojevskij zachycuje v dílech krátký časový úsek, v němž postava přichází k zjištění, že její směrování není správné, je nucena ho přehodnotit, pozměnit nebo úplně změnit. Následně vidíme postavu s odstupem času. Na základě vzájemného vztahu postavy a př́iběhu vznikaly později další typologie románu.

\section{Další souvislosti}

Chtěli bychom ještě poukázat na souvislost, kterou nám evokuje Forster, když píše o příběhu jako o tzv. zdroji hlasu (the story as the repository of a voice); hlas nás přitom jako antropologický termín opět odkazuje k člověku, ale také k hudbě: „Tento aspekt románopiscovej práce si žiada čítanie nahlas, prihovára sa nie oku, ako väčšina prózy, ale uchu; v tomto ohl'ade má mnoho spoločného s rečníctvom. "46 Pojem hlas se nám automaticky pojí s M. Bachtinem a jeho interpretací Dostojevského románu jako románu polyfonního (polifoničeskij), mnohohlasého (mnogogolosyj), v němž každá postava reprezentuje svůj hlas, je autorem vlastní ideje, vlastní filosofické koncepce. ${ }^{47}$ Ve Forsterově pojetí jde však o spojení příběhu se zvukem; o libozvuk, jenž se vytrácí, pokud se příběh nečte hlasitě.

Ve spojitosti s postavami se Forster krátce vyjadřuje ještě o dalším žánru - o memoárech: „memoáre - to jest história, sa zakladajú na svedectve. “48 Již slovy historie (history) a svědectvi nebo důkaz (evidence) jasně zdůrazňuje nefikci, nefikční základ memoárů; jinými slovy řečeno, memoáry řadí k věcné literatuře. Přitom román, založený na skutečných událostech, modifikuje podle Forstera tzv. temperament romanopisce (temperament of a novelist). Jak můžeme vidět, tento typ románu Forster neklade na stejnou pozici jako memoáry, protože projevení temperamentu autora v románu může být různé, větší

tím, že nadřazovali děj postavě a obráceně, tyto dvě kategorie jednou provždy neoddělitelně propojili: z dnešního hlediska se zdá, že tato dvě pojetí jsou bezezbytku komplementárni, že tvoři jisté kontinuum (a zároveň stráži jeho hranice), v jehož rámci se odehrává podstatná část moderního naratologického zkoumání literárních postav [...].“ FOǨT, Bohumil: Literární postava. Praha: Ústav pro českou literaturu AV ČR, 2008, s. 20.

44 Tamtéž, s. 19.

45 ČERVEŇÁK, Andrej: Zázračno literatúry I. Ruská klasika. Nitra: Fakulta humanitných vied VŠPg, 1994, s. 26.

46 FORSTER, Edward Morgan: Aspekty románu. Bratislava: Tatran, 1971, s. 52.

47 Srov. BACHTIN, M. M.: Problémy poetiky románu. Bratislava: Slovenský spisovatel', 1973, s. 196. Práce M. M. Bachtina Problémy tvorby Dostojevského (Problemy tvorčestva Dostojevskogo, 1929) vychází koncem dvacátých let, její druhé, doplněné vydání s názvem Problémy poetiky Dostojevského (Problemy poetiky Dostojevskogo, 1963) v šedesátých letech.

FORSTER, Edward Morgan: Aspekty románu. Bratislava: Tatran, 1971, s. 55. 
nebo menší; v každém případě posouvá román dále od nefikce, věcné literatury, blíže $\mathrm{k}$ beletrii a literatuře fikční.

\section{Místo závěru}

Prostřednictvím monografie Aspects of the Novel (1927) E. M. Forster vstupuje do polemiky s literárním teoretikem Percy Lubbockem, konkrétně s jeho prací The Craft of Fiction, která vyšla o něco dříve, již v roce 1921. A nejen s Lubbockem, ale i dalšími osobnostmi, jako byli W. James a T. S. Eliot. Konkrétně na T. S. Eliota se Forster odvolává v souvislosti s literární tradicí, kterou definuje jako „hraničné územie, ktoré leži medzi literatúrou a históriou, dobre vyzbrojený kritik môže na tomto územi strávit’ mnoho času a vel’a ziskat’ pre seba. "49 Následně vtipně poznamenává: „My sa tam ale nemôžeme vydat', pretože sme toho dost’ neprečítali. " ${ }^{50}$ Podle Forstera př́nos spisovatele nemusíme hodnotit jen v souvislosti s tradicí, z čehož plyne, že kategorie času nebyla pro něj až tak důležitá. Naopak T. S. Eliot v eseji Tradition and the Individual Talent poukazuje na důležitost definovat přínos daného spisovatele v souvislosti s jeho předchůdci. V českém prostředí se významem literární tradice zabývali strukturalisté, připomeňme například práce Felixe Vodičky.

Již rok po Forsterových Aspektech vychází monografie anglosaského literárního kritika a teoretika Edwina Muira The Structure of the Novel. Poukazuje v ní na Forsterovo odmítání podřídit se jednomu aspektu, přičemž jeho zaměření na postavy Muir vysvětluje na základě faktu, že jako spisovatel píśící romány měl Forster k postavám blízko: „Mr Forster does not hold much with form; he sees no reason why a novel should stick to one 'point of view'; he is content so long as the novelist 'bounces' us into a belief in his characters and gives us 'life." "51 Muir zároveň zdůrazňuje propojenost románu, a tím literatury jako druhu umění se životem: „Mr Forster argues that the novel must give us life, because life does [...]."52

Forsterova monografie představuje svým charakterem zčásti polemiku (Lubbock, James, Eliot), která již v době svého vzniku získala ohlas v pracích dalších literárních vědců (Muir aj.), navíc dnes s jistotou můžeme říct, že je považována za jednu ze stěžejních prací vážících se $\mathrm{k}$ teorii románu. Jelikož z pohledu dneška byla samozřejmě vícekrát překonána, jak v souvislosti s definicí románu založené na kvantitativním hledisku, tak i s dualistickou typologií postav, podle nás je inspirativní dodnes, a to myšlenkou i jazykem, přístupem s nadhledem a samozřejmě souvislostmi s ruskou literaturou, na které jsme se v textu naší práce snažili poukázat. A nejen tím. Forsterovy práce nás inspirují také antropologickým přístupem, jenž se projevuje v zaměření na postavu, čímž se však neztrácí vnímání románu jako celku skládajícího se ze souboru aspektů. Eseje The Creator as a Critic a The Brothers Karamazov and Bhakti uvedené souvislosti ještě více akcentují.

49 Tamtéž, s. 41.

50 Tamtéž.

51 MUIR, Edwin: The Structure of the Novel. London: The Hogarth Press, 1946, s. 8.

52 Tamtéž, s. 10. 


\title{
Literatura
}

BACHTIN, M. M.: Problémy poetiky románu. Bratislava: Slovenský spisovatel', 1973.

ČERVEŇÁK, Andrej: Zázračno literatúry I. Ruská klasika. Nitra: Vysoká škola pedagogická v Nitre, 1994.

FORSTER, Edward Morgan: Aspekty románu. Bratislava: Tatran, 1971.

FORSTER, Edward Morgan: Aspects of the Novel. Harmondsworth: Penguin, 1976.

FORSTER, Edward Morgan: The Creator as a Critic. In: The Creator as a Critic and Other Writings by E. M. Forster. Edited by Jeffrey M. Heath. Toronto: Dundurn Press, 2008, s. 64-107.

FORSTER, Edward Morgan: The Brothers Karamazov and Bhakti. In: The Creator as a Critic and Other Writings by E. M. Forster. Edited by Jeffrey M. Heath. Toronto: Dundurn Press, 2008, s. 255-258.

FOŘT, Bohumil: Literárni postava. Praha: Ústav pro českou literaturu AV ČR, 2008.

HRABÁK, Josef: Poetika. Praha: Československý spisovatel, 1973.

LUBBOCK, Percy: The Craft of Fiction. London: Jonathan Cape, 1966.

MUIR, Edwin: The Structure of the Novel. London: The Hogharth Press, 1946.

POSPÍŠIL, Ivo: Rozpěti žánru. Brno: SPRINT-PRINT, 1992.

POSPÍŠIL, Ivo: Literárni genologie. Brno: Masarykova univerzita, 2014.

POSPÍŠIL, Ivo: Literární postava jako „zašité nůžky“ literárni vědy. In: Sborník prací Filozofické fakulty Brněnské univerzity, X 4, 2001, s. 51-57.

POSPÍŠIL, Ivo: Proti proudu. Studie o N. S. Leskovovi. Brno: SPRINT-PRINT, 1992.

POSPÍŠIL, Ivo: Ruská literatura z pozice charakterologie. In: Novaja rusistika 5, 2012, č. 1, s. 73-82.

ŠIMEČKOVÁ, Eva: Pokus E. M. Forstera o teóriu románu. In: FORSTER, E. M.: Aspekty románu. Bratislava: Tatran, 1971, s. 11-25.

ŠKLOVSKIJ, Viktor: Teória prózy. Bratislava: Tatran, 1971.

\author{
PaedDr. Lenka Paučová \\ Ústav slavistiky \\ Filozofická fakulta, Masarykova univerzita \\ Arna Nováka 1, 60200 Brno, Česká republika \\ lenka.paucova@mail.muni.cz
}


